\title{
Synthesis, characterization, DFT calculations and antimicrobial activity of Cd(II) complexes with the condensation product of 2 - quinolinecarboxaldehyde and Girard's T reagent
}

\author{
Mima Č. Romanović, Božidar Čobeljić, Andrej Pevec, Iztok Turel, Sonja \\ Grubišić, Dušanka Radanović, Katarina Anđelković, Marina Milenković \& \\ Milica R. Milenković
}

To cite this article: Mima Č. Romanović, Božidar Čobeljić, Andrej Pevec, Iztok Turel, Sonja Grubišić, Dušanka Radanović, Katarina Anđelković, Marina Milenković \& Milica R. Milenković (2017): Synthesis, characterization, DFT calculations and antimicrobial activity of $\mathrm{Cd}(\mathrm{II})$ complexes with the condensation product of 2-quinolinecarboxaldehyde and Girard's T reagent, Journal of Coordination Chemistry, DOI: 10.1080/00958972.2017.1405262

To link to this article: http://dx.doi.org/10.1080/00958972.2017.1405262

Accepted author version posted online: 13

Nov 2017.

Submit your article to this journal $\sqsubset$

Q View related articles $\square$

View Crossmark data ऍ 
Publisher: Taylor \& Francis

Journal: Journal of Coordination Chemistry

DOI: http://doi.org/10.1080/00958972.2017.1405262

\section{Synthesis, characterization, DFT calculations and antimicrobial activity of Cd(II) complexes with the condensation product of 2-quinolinecarboxaldehyde and Girard's T reagent}

MIMA Č. ROMANOVIĆa, BOŽIDAR ČOBELJIĆa, ANDREJ PEVEC ${ }^{b}$, IZTOK TUREL $^{\mathrm{b}}$, SONJA GRUBIŠIĆc DUŠANKA RADANOVIĆc, KATARINA ANĐELKOVIĆa ${ }^{a}$, MARINA MILENKOVIĆ ${ }^{\mathrm{d}}$ and MILICA R. MILENKOVIĆ*a

aFaculty of Chemistry, University of Belgrade, Studentski trg 12-16, 11000 Belgrade, Serbia

${ }^{b}$ Faculty of Chemistry and Chemical Technology, University of Ljubljana, Večna pot 113, 1000 Ljubljana, Slovenia 'Institute of Chemistry, Technology and Metallurgy, University of Belgrade, Njegoševa 12, P.O. Box 815, 11000 Belgrade, Serbia

${ }^{d}$ Faculty of Pharmacy, Department of Microbiology and Immunology, University of Belgrade, Vojvode Stepe 450, 11221 Belgrade, Serbia

The chloro (1) and isocyanato (2) Cd(II) complexes with the condensation product of 2-quinolinecarboxaldehyde and trimethylammonium acetohydrazide chloride (Girard's T reagent) ( $\mathrm{HLCl}$ ) have been synthesized and characterized by elemental analysis, IR and NMR spectroscopy. The crystal structure of chloro Cd(II) complex (1) was determined. In $\mathbf{1}$ and $\mathbf{2}$, coordination surrounding of $\mathrm{Cd}(\mathrm{II})$ consists of deprotonated hydrazone ligand coordinated through NNO-donor atoms and two monodentates at the rest of the coordination places. Quantum-chemical calculations of the molecular structures and the relative stabilities of linkage isomers of the $\mathrm{Cd}(\mathrm{II})$ complex showed that the isomer with $\mathrm{N}-\mathrm{Cd}-\mathrm{N}$ coordination of $\mathrm{OCN}^{-}$is the most stable. The investigated $\mathrm{Cd}(\mathrm{II})$ complexes showed lower activity than standard antimicrobial drugs.

Keywords: Cd(II) Complexes; Hydrazones; Crystal structure; Antimicrobial activity; DFT

\section{Introduction}

Pseudohalide Cd(II) complexes can exhibit a wide variety of coordination numbers and geometries in their mono-, di- and polynuclear complexes, due to the large radius and $\mathrm{d}^{10}$

*Corresponding author. Email: mrm@chem.bg.ac.rs 
configuration of $\mathrm{Cd}(\mathrm{II})$ [1-4]. Not only interesting structures, but also luminescence and fluorescence properties, attracted the attention towards the research of this class of compounds [5-8]. Halides and pseudohalides are versatile building blocks which can bind as monodentate or as bridges between metal centers. Among them, azide is the most used for the synthesis of polynuclear complexes and their supramolecular frameworks due to its versatile bridging coordination modes, single and double: $\mu_{1,3}-\mathrm{N}_{3}$ (end-to-end, EE) and $\mu_{1,1}-\mathrm{N}_{3}$ (end-on, EO), $\mu_{1,1,3}-\mathrm{N}_{3}, \mu_{1,1,1}-\mathrm{N}_{3}, \mu_{1,1,1,1}-\mathrm{N}_{3}, \mu_{1,1,3,3}-\mathrm{N}_{3}$, and $\mu_{1,1,1,3,3,3}-\mathrm{N}_{3}$ [9]. Cyanato ligand can be coordinated as monodentate or bridging ligand (end-on $\mu_{1,1}-\kappa_{\mathrm{N}}$ and $\mu_{1,1}-\kappa_{\mathrm{O}}$ or end-to-end $\mu_{1,3}$ ) through oxygen or nitrogen donor atoms, although coordination through oxygen is rare [10].

Cadmium was recognized as a human carcinogen by the International Agency for Research on Cancer due to its known toxicity [11]. The toxicity of cadmium depends on the nature of anion in its salts and can be modulated by complexation [12]. Although cadmium is generally known to be extremely toxic to mammals, it is not true that it is not used by nature in any way. A unicellular microalga Thalassiosira weissflogii flourishes in environments with high cadmium [13]. If there is not enough zinc in the environment, the diatom uses cadmium instead of zinc as a cofactor of carbonic anhydrase enzyme [14]. Biological activity of Cd(II) complexes was not the subject of intensive research, but some studies which deal with DNA-binding ability, antibacterial and antitumor activity of Cd(II) complexes are reported $[11,12,15,16]$. One part of our research deals with systematic investigation of coordination chemistry, magnetic properties and biological activity of hydrazone metal complexes with pseudohalide ligands. Recently, we systematically investigated pseudohalide complexes of $\mathrm{Ni}(\mathrm{II})$ and $\mathrm{Zn}$ (II) with the condensation product of 2-quinolinecarboxaldehyde and trimethylammonium acetohydrazide chloride (Girard's T reagent) (HLCl) [17, 18]. As a continuation of this research, reactions of Cd(II) with $\mathrm{HLCl}$ ligand and pseudohalides (azide, cyanate, thiocyanate) were performed in the present study. Mononuclear chloro $\left[\mathrm{CdLCl}_{2}\right] \cdot \mathrm{CH}_{3} \mathrm{OH}(\mathbf{1})$ and isocyanato $\left[\mathrm{CdL}(\mathrm{NCO})_{2}\right](2) \mathrm{Cd}(\mathrm{II})$ complexes were obtained, structurally characterized and their antimicrobial activity was tested.

\section{Experimental}

\subsection{Materials and methods}

2-Quinolinecarboxaldehyde (97\%) Girard's T reagent (99\%), $\mathrm{Cd}\left(\mathrm{NO}_{3}\right) \cdot 4 \mathrm{H}_{2} \mathrm{O}(98 \%), \mathrm{NH}_{4} \mathrm{SCN}$ ( $\geq 97.5 \%), \mathrm{NaOCN}(\geq 99.5 \%)$ and $\mathrm{NaN}_{3}(96 \%)$ were obtained from Aldrich. IR spectra were 
recorded on a Nicolet 6700 FT-IR spectrometer using the ATR technique from 4000-400 $\mathrm{cm}^{-1}$ (vs = very strong, $\mathrm{s}=$ strong, $\mathrm{m}=$ medium and $\mathrm{w}=$ weak $) .{ }^{1} \mathrm{H}(500 \mathrm{MHz}),{ }^{13} \mathrm{C}(125 \mathrm{MHz})$ and 2-D NMR spectra of $\mathrm{HLCl}$ and Cd(II) complexes were recorded on a Bruker Avance 500 spectrometer at room temperature using TMS as internal standard in methanol- $d^{4}$ in the case of $\mathrm{HLCl}$ and $\mathrm{DMSO}-d^{6}$ in the case of Cd(II) complexes (see Supporting Information). Chemical shifts $(\delta)$ are expressed in ppm and coupling constants $(J)$ in Hz. Elemental analyses $(\mathrm{C}, \mathrm{H}$ and N) were performed by standard micro-methods using the ELEMENTARVario ELIII C.H.N.S.O analyzer. Molar conductivities were measured at room temperature $\left(25^{\circ} \mathrm{C}\right)$ on a digital conductivity-meter JENWAY-4009.

\subsection{Synthesis}

2.2.1. Synthesis of (E)-N,N,N-trimethyl-2-oxo-2-(2-(quinolin-2-ylmethylene)hydrazinyl)ethan-1-aminium chloride (HLCl). $\mathrm{HLCl}$ was synthesized in the reaction of 2-quinolinecarboxaldehyde and Girard's $T$ reagent according to the previously described method [17]. IR ( $\left.\mathrm{cm}^{-1}\right): 3414(\mathrm{~m}), 3062(\mathrm{~m}), 2970(\mathrm{~m}), 2939(\mathrm{~m}), 2831(\mathrm{~m}), 1699(\mathrm{~s}), 1595(\mathrm{~m}), 1562(\mathrm{w})$, 1497(m), 1414(m), 1379(w), 1340(w), 1301(m), 1230(m), 1135(m), 989(w), 950(w), 916(w), 868(w), 832(w), 758(m), 656(w), 633(w), 533(w). ${ }^{1} \mathrm{H}$ NMR (500 MHz, $\mathrm{CD}_{3} \mathrm{OD}$ ) (numbering of atoms according to scheme 1), $\delta$ (ppm): $3.47(\mathrm{~s}, 9 \mathrm{H}, \mathrm{C} 12-\mathrm{H}), 4.94(\mathrm{~s}, 2 \mathrm{H}, \mathrm{C} 11-\mathrm{H}), 8.17(\mathrm{~s}, 1 \mathrm{H}$, $\mathrm{C} 9-\mathrm{H}), 8.18\left(\mathrm{~d}, 1 \mathrm{H},{ }^{3} J_{\mathrm{C} 3-\mathrm{H} / \mathrm{C} 4-\mathrm{H}}=10 \mathrm{~Hz}, \mathrm{C} 3-\mathrm{H}\right), 8.36\left(\mathrm{~d}, 1 \mathrm{H},{ }^{3} J_{\mathrm{C} 3-\mathrm{H} / \mathrm{C} 4-\mathrm{H}}=10 \mathrm{~Hz}, \mathrm{C} 4-\mathrm{H}\right), 7.94(\mathrm{~d}$, $\left.1 \mathrm{H},{ }^{3} J_{\mathrm{C} 5-\mathrm{H} / \mathrm{C} 6-\mathrm{H}}=5 \mathrm{~Hz}, \mathrm{C} 5-\mathrm{H}\right), 7.62\left(\mathrm{t}, 1 \mathrm{H},{ }^{3} J_{\mathrm{C} 5-\mathrm{H} / \mathrm{C} 6-\mathrm{H} / \mathrm{C} 7-\mathrm{H}}=5 \mathrm{~Hz}, \mathrm{C} 6-\mathrm{H}\right), 7.78(\mathrm{t}, 1 \mathrm{H}$, $\left.{ }^{3} J_{\mathrm{C} 6-\mathrm{H} / \mathrm{C} 7 \mathrm{H} / \mathrm{C} 8-\mathrm{H}}=5 \mathrm{~Hz}, \mathrm{C} 7-\mathrm{H}\right), 8.03\left(\mathrm{~d}, 1 \mathrm{H},{ }^{3} J_{\mathrm{C} 7-\mathrm{H} / \mathrm{C} 8-\mathrm{H}}=5 \mathrm{~Hz}, \mathrm{C} 8-\mathrm{H}\right) .{ }^{13} \mathrm{C} \mathrm{NMR}(125 \mathrm{MHz}$, $\mathrm{CD}_{3} \mathrm{OD}$ ) (numbering of atoms according to scheme 1), $\delta$ (ppm): 55.0 (C12), 64.4 (C11), 146.9 (C9), 154.4 (C2), 119.2 (C3), 138.7 (C4), 130.1 (C4a), 129.3 (C5), 129.0 (C6), 131.7 (C7), 129.7 (C8), 148.9 (C8a), 167.0 (C10).

\subsubsection{Synthesis of dichloro (E)-N,N,N-trimethyl-2-oxo-2-(2-(quinolin-2-}

\section{ylmethylene)hydrazinyl)ethan-1-aminium cadmium(II) complex monomethanole}

$\left[\mathbf{C d L C l}_{2}\right] \cdot \mathbf{C H}_{\mathbf{3}} \mathbf{O H}(\mathbf{1})$. $\mathrm{HLCl}(90 \mathrm{mg}, 0.30 \mathrm{mmol})$ was dissolved in methanol $(20 \mathrm{~mL})$ and solid $\mathrm{Cd}\left(\mathrm{NO}_{3}\right)_{2} \cdot 4 \mathrm{H}_{2} \mathrm{O}(120 \mathrm{mg}, 0.30 \mathrm{mmol})$ was added. After complete dissolution of $\mathrm{Cd}\left(\mathrm{NO}_{3}\right)_{2} \cdot 4 \mathrm{H}_{2} \mathrm{O}$ in the reaction mixture, $\mathrm{NaN}_{3}(40 \mathrm{mg}, 0.60 \mathrm{mmol})$ dissolved in water $(10 \mathrm{~mL})$ was added. The yellow reaction solution was stirred at $65^{\circ} \mathrm{C}$ for $3 \mathrm{~h}$. After slow evaporation of solvent in a 
refrigerator $\left(\sim 4^{\circ} \mathrm{C}\right)$ for five days, yellow crystals were obtained. Yield: $57 \mathrm{mg}(39 \%)$. Elemental

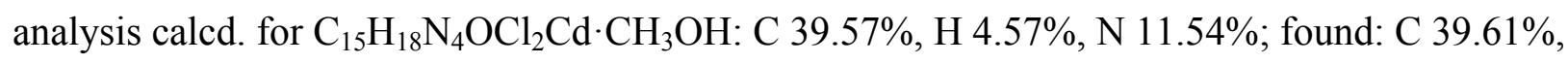
H 4.65\%, N 11.51\%. IR (cm-1): 3282(m), 3077(w), 3019(w), 2934(w), 2814(w), 2042(w), 1610(w), 1565(s), 1535(s), 1509(m), 1487(m), 1450(w), 1431(w), 1395(m), 1344(w), 1325(w), 1295(s), 1229(w), 1204(w), 1128(w), 1083(s), 1034(m), 969(w), 919(m), 826(w), 784(w), 760(w). ${ }^{1} \mathrm{H}$ NMR $\left(500 \mathrm{MHz}, \mathrm{DMSO}-d^{6}\right)$ (numbering of atoms according to scheme 1), $\delta$ (ppm): 3.25 (s, 9H, C12-H), 4.09 (s, 2H, C11-H), 8.60 (s, 1H, C9-H), $7.71\left(\mathrm{t}, 1 \mathrm{H},{ }^{3} J_{\mathrm{C} 3-\mathrm{H} / \mathrm{C} 4-\mathrm{H}}=10 \mathrm{~Hz}\right.$, $\mathrm{C} 3-\mathrm{H}), 8.09\left(\mathrm{~d}, 1 \mathrm{H},{ }^{3} J_{\mathrm{C} 3-\mathrm{H} / \mathrm{C} 4-\mathrm{H}}=10 \mathrm{~Hz}, \mathrm{C} 4-\mathrm{H}\right), 8.40\left(\mathrm{~d}, 1 \mathrm{H},{ }^{3} J_{\mathrm{C} 5-\mathrm{H} / \mathrm{C} 6-\mathrm{H}}=10 \mathrm{~Hz}, \mathrm{C} 5-\mathrm{H}\right), 7.89(\mathrm{~m}$, 1H, C6-H), 7.89 (m, 1H, C7-H), 8.67 (d, 1H, $\left.{ }^{3} J_{\mathrm{C} 7-\mathrm{H} / \mathrm{C} 8-\mathrm{H}}=10 \mathrm{~Hz}, \mathrm{C} 8-\mathrm{H}\right) .{ }^{13} \mathrm{C} \mathrm{NMR}(125 \mathrm{MHz}$, DMSO- $d^{6}$ ) (numbering of atoms according to scheme 1), $\delta(\mathrm{ppm}): 53.7$ (C12), 67.5 (C11), 143.2 (C9), 149.6 (C2), 128.3 (C3), 128.6 (C4), 129.4 (C4a), 128.2 (C5), 123.5 (C6), 131.9 (C7), 140.3 (C8), $146.0(\mathrm{C} 8 \mathrm{a}), 171.9(\mathrm{C} 10) . \Lambda_{\mathrm{M}}(1 \mathrm{mM}, \mathrm{DMSO}): 14.3 \Omega^{-1} \mathrm{~cm}^{2} \mathrm{~mol}^{-1}$.

\subsubsection{Synthesis of diisocyanato (E)-N,N,N-trimethyl-2-0xo-2-(2-(quinolin-2-} ylmethylene)hydrazinyl)ethan-1-aminium cadmium(II) complex [CdL(NCO) $)_{2}$ (2). Into a solution of $\mathrm{HLCl}(90 \mathrm{mg}, 0.30 \mathrm{mmol})$ in methanol $(20 \mathrm{~mL})$, solid $\mathrm{Cd}\left(\mathrm{NO}_{3}\right)_{2} \cdot 4 \mathrm{H}_{2} \mathrm{O}(120 \mathrm{mg}$, $0.30 \mathrm{mmol}$ ) was added. After complete dissolution of $\mathrm{Cd}(\mathrm{II})$ salt in reaction solution, $\mathrm{NaOCN}$ $(80 \mathrm{mg}, 1.20 \mathrm{mmol})$ dissolved in water $(10 \mathrm{~mL})$ was added. The reaction mixture was stirred for $3 \mathrm{~h}$ at $100{ }^{\circ} \mathrm{C}$. After slow evaporation of solvent in a refrigerator $\left(\sim 4{ }^{\circ} \mathrm{C}\right)$ for ten days yellow crystals were obtained. Yield. $41 \mathrm{mg}(29 \%)$. Elemental analysis calcd. for $\mathrm{C}_{17} \mathrm{H}_{18} \mathrm{~N}_{6} \mathrm{O}_{3} \mathrm{Cd}$ : C 43.74\%, H 3.89\%, N 18.00\%; found: C 43.86\%, H 3.93\%, N 17.98\%. IR (cm $\left.{ }^{-1}\right): 3519(\mathrm{w})$, 3460(w), 2197(vs), 1618(w), 1560(m), 1524(s), 1470(s), 1408(m), 1389(m), 1329(m), 1298(m), 1227(w), 1196(w), 1111(w), 1074(m), 989(w), 970(w), 921(m), 835(w), 810(w), 782(w), 752(m), 624(w). ${ }^{1} \mathrm{H}$ NMR (500 MHz, DMSO- $d^{6}$ ) (numbering of atoms according to scheme 1), $\delta(\mathrm{ppm}): 3.26(\mathrm{~s}, 9 \mathrm{H}, \mathrm{C} 12-\mathrm{H}), 4.10(\mathrm{~s}, 2 \mathrm{H}, \mathrm{C} 11-\mathrm{H}), 8.62(\mathrm{~s}, 1 \mathrm{H}, \mathrm{C} 9-\mathrm{H}), 7.71\left(\mathrm{~d}, 1 \mathrm{H},{ }^{3} J_{\mathrm{C} 3-\mathrm{H} / \mathrm{C} 4-\mathrm{H}}=\right.$ $10 \mathrm{~Hz}, \mathrm{C} 3-\mathrm{H}), 8.09\left(\mathrm{~d}, 1 \mathrm{H},{ }^{3} J_{\mathrm{C} 3-\mathrm{H} / \mathrm{C} 4-\mathrm{H}}=10 \mathrm{~Hz}, \mathrm{C} 4-\mathrm{H}\right), 8.28\left(\mathrm{~d}, 1 \mathrm{H},{ }^{3} J_{\mathrm{C} 5-\mathrm{H} / \mathrm{C} 6-\mathrm{H}}=10 \mathrm{~Hz}, \mathrm{C} 5-\mathrm{H}\right)$, $7.92(\mathrm{~m}, 1 \mathrm{H}, \mathrm{C} 6-\mathrm{H}), 7.92(\mathrm{~m}, 1 \mathrm{H}, \mathrm{C} 7-\mathrm{H}), 8.68\left(\mathrm{~d}, 1 \mathrm{H},{ }^{3} J_{\mathrm{C} 7-\mathrm{H} / \mathrm{C} 8-\mathrm{H}}=10 \mathrm{~Hz}, \mathrm{C} 8-\mathrm{H}\right) .{ }^{13} \mathrm{C} \mathrm{NMR}$ (125 MHz, DMSO- $d^{6}$ ) (numbering of atoms according to scheme 1), $\delta$ (ppm): 53.7 (C12), 67.4 (C11), 143.8 (C9), 149.7 (C2), 128.2 (C3), 128.7 (C4), 129.4 (C4a), 127.6 (C5), 123.6 (C6), $132.1(\mathrm{C} 7), 140.4(\mathrm{C} 8), 146.0(\mathrm{C} 8 \mathrm{a}), 172.0(\mathrm{C} 10), 127.8\left(\mathrm{OCN}^{-}\right) . \Lambda_{\mathrm{M}}(1 \mathrm{mM}, \mathrm{DMSO}): 10.6 \Omega^{-1}$ $\mathrm{cm}^{2} \mathrm{~mol}^{-1}$. 


\subsection{X-ray structure determination}

Crystal data and refinement parameters of $\mathbf{1}$ are listed in table 1. Selected bond distances and angles are listed in table 2. The X-ray intensity data were collected at room temperature with a Nonius Kappa CCD diffractometer equipped with graphite-monochromated Mo Ka radiation $(\lambda=0.71073 \AA)$. The data were processed using DENZO [19]. The structure was solved by direct methods implemented in SHELXS-2013 [20] and refined by full-matrix least-squares based on $F^{2}$ using SHELXL-2016 [20]. All non-hydrogen atoms were refined anisotropically. The C10- and O2-bound hydrogens were located in a difference map and refined with distance restraints (DFIX) of C-H $=0.98$ or $\mathrm{O}-\mathrm{H}=0.82 \AA$ and with $U_{\text {iso }}(\mathrm{H})=1.2 U_{\mathrm{eq}}(\mathrm{C})$ or $U_{\text {iso }}(\mathrm{H})=$ $1.5 U_{\text {eq }}(\mathrm{O})$, respectively. All other hydrogens were included in the model at geometrically calculated positions and refined using a riding model. ORTEP-3 for Windows was used to prepare drawings [21].

CCDC 1562578 contains the supplementary crystallographic data for $\mathbf{1}$. These data can be obtained free of charge from the Cambridge Crystallographic Data Center via www.ccdc.cam.ac.uk/data_request/cif.

\subsection{Antimicrobial activity}

Antimicrobial activity was investigated against seven laboratory control strains of bacteria i.e., gram-positive: Staphylococcus aureus (ATCC 6538), Staphylococcus epidermidis (ATCC 12228), Bacillus subtilis (ATCC 6633); gram-negative: Escherichia coli (ATCC 10536), Klebsiella pneumoniae (ATCC 13883), Pseudomonas aeruginosa (ATCC 9027) and Salmonella enterica subsp. abony (ATCC 6017) and one strain of yeast Candida albicans (ATCC 10231). In order to determine minimum inhibitory concentration (MIC) of tested compounds, a broth microdilution method was used according to Clinical and Laboratory Standards Institute guidelines CLSI (2016) [22] with some modifications. Tests were performed in Müller-Hinton broth for the bacterial strains and in Sabouraud dextrose broth for Candida albicans. The tested compounds were dissolved in 1\% dimethyl sulfoxide (DMSO) and then diluted to the highest concentration. Twofold serial concentrations of the compounds were prepared in a 96-well microtiter plate (ranging from $62.5-1000 \mu \mathrm{g} / \mathrm{mL}$ ) with addition of $0.05 \% 2,3,5$-triphenyl- $2 \mathrm{H}$ tetrazolium chloride (TTC, Sigma-Aldrich, USA) as a growth indicator. All of the MIC 
determinations were performed in duplicate, and two positive growth controls were included (wells containing only the microorganisms in the broth). Each test was repeated three times. Identical MIC values were obtained in all experiments for a particular substance and strain.

\section{Results and discussion}

\subsection{Synthesis}

The reaction of 2-quinolinecarboxaldehyde and Girard's T reagent was performed according to the previously reported method [17] yielding the ligand (E)-N,N,N-trimethyl-2-0xo-2-(2(quinolin-2-ylmethylene)hydrazinyl)ethan-1-aminium chloride (HLCl), which was used for the synthesis of $\mathbf{1}$ and $\mathbf{2}$ (scheme 1). Complex $\mathbf{1}$ was obtained via the reaction of HLCl with $\mathrm{Cd}\left(\mathrm{NO}_{3}\right)_{2} \cdot 4 \mathrm{H}_{2} \mathrm{O}$ and $\mathrm{NaN}_{3}$ in molar ratio 1:1:2 in methanol. In this reaction, the source of chloride anions was $\mathrm{HLCl}$ ligand itself, while azide anions deprotonated hydrazone ligand. The same reaction performed without $\mathrm{NaN}_{3}$ was unsuccessful since the products were unstable in reaction solution and decomposed to starting compounds. The synthesis of isothiocyanato/thiocyanato $\mathrm{Cd}(\mathrm{II})$ complexes in the reaction of $\mathrm{HLCl}$ with $\mathrm{Cd}\left(\mathrm{NO}_{3}\right)_{2} \cdot 4 \mathrm{H}_{2} \mathrm{O}$ and $\mathrm{SCN}^{-}$were also unsuccessful regardless of the source of $\mathrm{SCN}^{-}\left(\mathrm{KSCN}\right.$ or $\left.\mathrm{NH}_{4} \mathrm{SCN}\right)$ and molar ratio of the reactants. The reaction of $\mathrm{HLCl}$ with $\mathrm{Cd}\left(\mathrm{NO}_{3}\right)_{2} \cdot 4 \mathrm{H}_{2} \mathrm{O}$ and $\mathrm{NaOCN}$ in molar ratio 1:1:4 in methanol results in formation of 2 . The X-ray crystal structure of $\mathbf{1}$ showed that $\mathrm{Cd}(\mathrm{II})$ is five-coordinate with quinoline nitrogen, azomethine nitrogen and carbonyl oxygen atoms from hydrazone ligand and two monodentate chloro ligands. Tridentate NNO-coordination of hydrazone ligand in $\mathbf{2}$ is proposed from similarity of NMR spectral data for $\mathbf{1}$ and $\mathbf{2}$. The presence of $\mathrm{OCN}^{-}$in 2 is evidenced from its IR and ${ }^{13} \mathrm{C}$ NMR spectra. The molar conductivity values of 1 and 2 in DMSO are $14.3 \Omega^{-1} \mathrm{~cm}^{2} \mathrm{~mol}^{-1}$ and $10.6 \Omega^{-1} \mathrm{~cm}^{2} \mathrm{~mol}^{-1}$, respectively. These values are lower than $35 \Omega^{-1} \mathrm{~cm}^{2} \mathrm{~mol}^{-1}$ [23], so $\mathbf{1}$ and $\mathbf{2}$ are non-electrolytes and are stable in DMSO. Having all these facts in mind as well as the results of elemental analysis, in 2 coordination environment of $\mathrm{Cd}(\mathrm{II})$ consists of quinoline nitrogen, azomethine nitrogen and carbonyl oxygen atoms from hydrazone ligand and two monodentate OCN- ligands.

\subsection{Spectroscopy}

3.2.1. IR spectra. On the basis of IR spectroscopy results, coordination of $\mathrm{HLCl}$ ligand in deprotonated $\alpha$-oxyazine form in $\mathbf{1}$ and $\mathbf{2}$ was confirmed. The new band at $1535 \mathrm{~cm}^{-1}$ in the 
spectrum of 1 and at $1524 \mathrm{~cm}^{-1}$ in the spectrum of 2 corresponding to $v\left({ }^{-} \mathrm{O}-\mathrm{C}=\mathrm{N}\right)$ vibration of deprotonated hydrazine moiety appeared instead of the band of carbonyl group of noncoordinated hydrazonic form of $\mathrm{HLCl}$ at $1699 \mathrm{~cm}^{-1}$. In the IR spectrum of 2 a strong band at $2197 \mathrm{~cm}^{-1}$ can be attributed to vibration of coordinated cyanate ions [24].

3.2.2. NMR spectra. The signal of hydrazide NH is absent in the ${ }^{1} H$ NMR spectra of $\mathbf{1}$ and $\mathbf{2}$, indicating that the ligand is coordinated in deprotonated zwitterionic form. Coordination of azomethine nitrogen in $\mathbf{1}$ and $\mathbf{2}$ can be confirmed from downfield shift of $\mathrm{C} 9-\mathrm{H}$ from $8.17 \mathrm{ppm}$ in the spectrum of $\mathrm{HLCl}$ to $8.60 \mathrm{ppm}$ and $8.62 \mathrm{ppm}$ in spectra of $\mathbf{1}$ and $\mathbf{2}$, respectively. Due to coordination of carbonyl oxygen atom, signal of the carbonyl carbon (C10) is shifted downfield from $167.0 \mathrm{ppm}$ in the spectrum of $\mathrm{HLCl}$ to $171.9 \mathrm{ppm}$ and $172.0 \mathrm{ppm}$ in the spectra of $\mathbf{1}$ and $\mathbf{2}$, respectively. Upfield shift of azomethine carbon atom (C9) signal from $146.9 \mathrm{ppm}$ in the spectrum of $\mathrm{HLCl}$ to $143.2 \mathrm{ppm}$ in the spectrum of $\mathbf{1}$ and 143.8 in the spectrum of $\mathbf{2}$ indicates coordination of azomethine nitrogen. Coordination of quinoline nitrogen atom caused upfield shift of $\mathrm{C} 2$ atom signal from $154.4 \mathrm{ppm}$ in the spectrum of $\mathrm{HLCl}$ to $149.6 \mathrm{ppm}$ and $149.7 \mathrm{ppm}$ in the spectra of $\mathbf{1}$ and $\mathbf{2}$, respectively. In the ${ }^{13} \mathrm{C}$ NMR spectrum of $\mathbf{2}$ the signal of coordinated $\mathrm{OCN}^{-}$ion was observed at $127.8 \mathrm{ppm}$.

\subsection{Description of the crystal structure}

The molecular structure (ORTEP) of $\mathbf{1}$ is depicted in figure 1. In $\mathbf{1}, \mathrm{Cd} 1$ has fivefold coordination with tridentate ligand $\mathrm{L}$ and two $\mathrm{Cl}^{-}$ligands $(\mathrm{Cl} 1$ and $\mathrm{Cl} 2)$. $\mathrm{L}$ is coordinated to $\mathrm{Cd} 1$ in the zwitterionic form through NNO-set of donor atoms forming two fused five-membered chelate rings. The dihedral angle of nearly $11.1^{\circ}$ between two five-membered chelate rings fused along Cd1-N2 junction during complexation shows the non-coplanar nature of metal-ligand system. The coordination polyhedron formed around $\mathrm{Cd} 1$ is irregular in shape with very bent trans bond angles of $138.03(7)^{\circ}$ and $135.68(7)^{\circ}$ for $\mathrm{N} 2-\mathrm{Cd} 1-\mathrm{Cl} 1$ and $\mathrm{N} 1-\mathrm{Cd} 1-\mathrm{O} 1$, respectively. The out-ofplane cis bond angles span the range from 97.40(7) to $116.85(3)^{\circ}$ and the in-plane cis bond angles are $67.46(7)$ to $106.32(6)^{\circ}$. The smallest values of $67.46(7)^{\circ}$ and $70.31(8)^{\circ}$ have been observed for bite angles N2-Cd1-O1 and N1-Cd1-N2, respectively. Solvent molecule serving as $\mathrm{H}$-bond donor is involved in discrete intermolecular hydrogen bond with deprotonated amide nitrogen which functions as an acceptor (figure 1, table S1, see Supporting Information). 
The distortion in the five coordinated systems is described by the trigonallity index, $\tau=$ $(\beta-\alpha) / 60$, where $\beta$ is the greatest basal angle and $\alpha$ is the second greatest angle [25]. The parameter $\tau$ is 0 for regular square based pyramidal forms and 1 for trigonal bipyramidal forms. The $\tau$ value of 0.04 in 1 indicates that the irregular coordination geometry about $\mathrm{Cd} 1$ is $4.0 \%$ trigonally distorted square-based pyramidal. The $\mathrm{Cd} 1$ is lifted out of the plane of the four inplane ligand atoms (N1, N2, O1 and C11) by a distance $\rho$ of 0.7024(2) $\AA$. The axial Cd1-C12 bond is slightly longer than the equatorial Cd1-Cl1 bond (2.466(1) versus 2.424(2) $\AA$ ). The other metal-ligand bond distances are in the order $\mathrm{Cd}-\mathrm{N}_{\text {heteroaromatic }}(2.408(2) \AA)>\mathrm{Cd}-\mathrm{O}_{\text {amide }}$ $(2.375(2) \AA)>C d-\mathrm{N}_{\text {imine }}(2.278(2) \AA)$. The angular structural parameter $(\tau)$ of 1 has been compared with those of structurally related five-coordinate $\mathrm{Cd}(\mathrm{II})$ complexes with hydrazone ligands (table 3).

For the complexes listed, the value $\tau$ varies from 0.03 to 0.12 , indicating that these structures span the range of trigonally distorted square-pyramidal configurations. $\operatorname{The} \mathrm{Cd}(\mathrm{II})$ ions of these complexes are displaced by distance $\rho(\rho=0.0359(4)-0.8459$ (3) $\AA$ ) from the equatorial plane towards corresponding apical ligands. The angular structural parameter $\tau$ of previously analyzed five-coordinate $\mathrm{Zn}$ (II) complexes with hydrazone ligands comprises the range from 0.13 to 0.40 [18], indicating that these complexes also span the range of trigonally distorted square-pyramidal configurations. However, $\mathrm{Zn}$ (II) complexes show greater trigonal distortion of square-based pyramidal configuration than $\mathrm{Cd}(\mathrm{II})$ complexes analyzed here, as indicated by the values $\tau$ listed in table 3 and those reported earlier [18].

In the crystals of 1 , the complex molecules are linked along the $b$-axis through $\pi \cdots \pi$ interactions between neighboring quinoline rings (figure 2, table 4).

\subsection{Computational studies}

The molecular structures of $\left[\mathrm{CdL}(\mathrm{NCO})_{2}\right](\mathrm{Cd}-1)$, $\left[\mathrm{CdL}(\mathrm{OCN})_{2}\right](\mathrm{Cd}-2)$ and $[\mathrm{CdL}(\mathrm{OCN})(\mathrm{NCO})]$ (Cd-3) have been optimized and analyzed by DFT computations. The initial geometries of investigated $\mathrm{Cd}(\mathrm{II})$ complexes were generated with completely linear $\mathrm{OCN}^{-}$and $\mathrm{NCO}^{-}$ligands. $\mathrm{XRD}$ structure of $\left[\mathrm{CdLCl}_{2}\right] \cdot \mathrm{CH}_{3} \mathrm{OH}$ was used as reference for typical five-coordinate $\mathrm{Cd}$ (II) complexes. Optimizations were carried out within DFT/B3LYP/3-21G approach in gas-phase, without any restrictions. Optimized geometries are shown in figure 3. The preference for $\mathrm{N}$-binding over $\mathrm{O}$ is found by comparing relative energies of $\mathrm{Cd}$ complexes: $\mathrm{N}-\mathrm{Cd}-\mathrm{N}$ 
coordination of $\mathrm{OCN}^{-}$is the most stable, the next in stability is $\mathrm{N}-\mathrm{Cd}-\mathrm{O}$ isomer $(\triangle E=$ $8.37 \mathrm{kcal} / \mathrm{mol})$ and the most destabilized is O-Cd-O isomer $(\Delta E=14.55 \mathrm{kcal} / \mathrm{mol})$. Selected bond lengths and angles of optimized structures are given in table 5.

Analysis of $\mathrm{Cd}(\mathrm{II})$ complexes containing two $\mathrm{NCO}^{-}$ligands in the Cambridge Structure Database [31] showed that, in majority of complexes, metal centers are bridged with $\mathrm{NCO}^{-}$ ligands ( 9 out of 16). Only six mononuclear $\mathrm{Cd}(\mathrm{II})$ complexes containing two monodentate $\mathrm{NCO}^{-}$ligands were found. In all of them, $\mathrm{NCO}^{-}$ligands are coordinated through nitrogen atom.

HOMO and LUMO orbitals of Cd(II) complexes are shown in figure 4. The HOMOs of all complexes are delocalized mainly at the linear group and metal center, whereas the LUMOs are delocalized on the planar ring of Schiff base. The preference for N-binding over O is found in the investigated isostructural $\mathrm{Cd}(\mathrm{II})$ complexes. The frontier molecular orbitals of $\mathrm{OCN}^{-}$and $\mathrm{NCO}^{-}$, specifically the $\pi$ (HOMO), both have primarily $\mathrm{N}$-character in all complexes (figure 4), which explains large isomerism energy.

Influences of $\mathrm{NCO}^{-}$and $\mathrm{OCN}^{-}$ligands on LUMO and $\mathrm{HOMO}$ are estimated by comparing energies of frontier molecular orbitals $\left(E_{\mathrm{LUMO}}, E_{\mathrm{HOMO}}\right)$ and their energy gap $\left(E_{\mathrm{gap}}\right)$. Substitution of $\mathrm{NCO}^{-}$with $\mathrm{OCN}^{-}$ligand has the same influence on HOMO and LUMO energy levels (table S2). Energies of HOMO and LUMO orbitals are the highest for Cd-2 complex but the $E_{\text {gap }}$ does not differ much from $E_{\text {gap in }}$ Cd-1 complex.

\subsection{Antimicrobial activity}

Complexes 1 and $\mathbf{2}$ showed lower activity than the standard antimicrobial drugs (meropenem and amphotericin, table 6). Isocyanato $\mathbf{2}$ exhibited better activity than chloro $\mathbf{1}$ against all tested microbial strains. These results indicate that antimicrobial activity of the investigated $\mathrm{Cd}(\mathrm{II})$ complexes depends on the nature of monodentate ligands. Complex 2 possesses better activity than Cd(II) salt against S. aureus, E. coli, K. pneumoniae, P. aeruginosa, S. enterica and S. epidermidis, but the activity of $\mathrm{Cd}(\mathrm{II})$ salt was better in the case of C. albicans and B. subtilis strains. HLCl showed lower activity than $\mathbf{2}$ against all examined microbial strains.

\section{Conclusion}

The reaction of $\mathrm{HLCl}$ with $\mathrm{Cd}\left(\mathrm{NO}_{3}\right)_{2} \cdot 4 \mathrm{H}_{2} \mathrm{O}$ and $\mathrm{NaN}_{3}$ in molar ratio 1:1:2 in methanol results in formation of chloro $\mathrm{Cd}(\mathrm{II})$ complex (1). The presence of excess of basic $\mathrm{N}_{3}{ }^{-}$caused 
deprotonation of $\mathrm{HLCl}$, while $\mathrm{Cl}^{-}$originating from $\mathrm{HLCl}$ coordinates to $\mathrm{Cd}(\mathrm{II})$. In the case of reaction of $\mathrm{HLCl}$ with $\mathrm{Cd}\left(\mathrm{NO}_{3}\right)_{2} \cdot 4 \mathrm{H}_{2} \mathrm{O}$ and $\mathrm{NaOCN}$ in molar ratio 1:1:4 in methanol basic $\mathrm{OCN}^{-}$ facilitate deprotonation of $\mathrm{HLCl}$ and coordinates to $\mathrm{Cd}(\mathrm{II})$ resulting in formation of 2 . In both $\mathbf{1}$ and 2, coordination surrounding of $\mathrm{Cd}$ (II) consists of deprotonated hydrazone ligand coordinated through NNO-set of donor atoms and two monodentates at the remaining coordination places. Since the X-ray determined structure of 2 was not obtained, DFT calculations were performed to give theoretical evidence about the coordination of $\mathrm{OCN}^{-}$ligand. The results showed that $\mathrm{N}-\mathrm{Cd}-\mathrm{N}$ coordination of $\mathrm{OCN}^{-}$is the most stable, the next in stability is $\mathrm{N}-\mathrm{Cd}-\mathrm{O}$ isomer $(\triangle E=$ $8.37 \mathrm{kcal} / \mathrm{mol})$ and the most destabilized is $\mathrm{O}-\mathrm{Cd}-\mathrm{O}$ isomer $(\triangle E=14.55 \mathrm{kcal} / \mathrm{mol})$. The obtained MIC values for $\mathbf{1}$ and $\mathbf{2}$ are higher than the values for standard antimicrobial drugs. Antimicrobial activity of the investigated Cd(II) complexes depends on the nature of monodentate ligand, since isocyanato Cd(II) complex (2) showed better activity than chloro $\mathrm{Cd}(\mathrm{II})$ complex (1) against all tested microbial strains. Complexation of $\mathrm{Cd}(\mathrm{II})$ with $\mathrm{NCO}^{-}$and $\mathrm{L}$ generally results in improvement of its antimicrobial activity. This effect can be attributed to sharing of positive charge of cadmium(II) ion with donor atoms of ligands which improved its lipophilicity and penetration through cell membranes of microorganism.

\section{Acknowledgements}

We thank EN-FIST Centre of Excellence, Trg OF 13, 1000 Ljubljana, Slovenia for use of the SuperNova diffractometer.

\section{Funding}

This work was supported by the Ministry of Education, Science and Technological development of the Republic of Serbia [grant number OI 172055] and the Slovenian Research Agency [grant number P1-0175]. Part of this work was supported by COST Action CM1305 “Explicit Control Over Spin-states in Technology and Biochemistry (ECOSTBio)" and was done during STSM, reference number COST-STSM-CM1305-37566. 


\section{References}

[1] W. You, J.-H. Guo, C.-P. Li, J. Chen. Polyhedron, 91, 104 (2015).

[2] J. Chen, M.-Z. Li, N. Sun, J.-H. Guo. J. Mol. Struct., 1105, 273 (2016).

[3] B.N. Sarkar, S. Choubey, K. Bhar, S. Chattopadhyay, P. Mitra, B.K. Ghosh. J. Mol. Struct., 994, 306 (2011).

[4] S. Ray, S. Konar, A. Jana, S. Jana, A. Patra, S. Chatterjee, J.A. Golen, A.L. Rheingold, S.S. Mandal, S.K. Kar. Polyhedron, 33, 82 (2012).

[5] I. Nawrot, K. Czerwińska, B. Machura, R. Kruszynski. J. Lumin., 181, 103 (2017).

[6] I. Nawrot, B. Machura, R. Kruszynski. Cryst. Eng. Comm., 18, 2650 (2016).

[7] W. Guo, Y.-Y. Yang, M. Du. Inorg. Chem. Commun., 13, 863 (2010).

[8] H.-Y. Zhao, F.-L. Yang, N. Li, X.-J. Wang. J. Mol. Struct., 1148, 62 (2017).

[9] A. Escuer, G. Aromí. Eur. J. Inorg. Chem., 4721 (2006).

[10] Z. Mahendrasinh, S. Ankita, S.B. Kumar, A. Escuer, E. Suresh. Inorg. Chim. Acta, 375, $333(2011)$.

[11] A. Zianna, M. Sumar Ristovic, G. Psomas, A. Hatzidimitriou, E. Coutouli-Argyropoulou, M. Lalia-Kantouri. J. Coord. Chem., 68, 4444 (2015).

[12] Manju, D. Kishore, D. Kumar. J. Coord. Chem., 64, 2130 (2011).

[13] J.G. Lee, S.B. Roberts, F.M.M. Morel. Limnol. Oceanogr., 40, 1056 (1995).

[14] T. Lane, M.A. Saito, G.N. George, I.J. Pickering, R.C. Prince, F.F.M. Morel. Nature, 435, $42(2005)$.

[15] L.L.L. Tévez, J.J.M. Medina, M.S. Islas, O.E. Piro, E.E. Castellano, L. Bruzzone, E.G. Ferrer, P.A.M. Williams. J. Coord. Chem., 64, 3560 (2011).

[16] C. Ma, S.-K Liang, F.-C. Zhao, Y. Meng, Y.-Y. Li, M.-C. Zhu, E.-J. Gao, J. Coord. Chem., 67, 3551 (2014).

[17] M.Č. Romanović, B.R. Čobeljić, A. Pevec, I. Turel, V. Spasojević, A.A. Tsaturyan, I.N. Shcherbakov, K.K. Anđelković, M. Milenković, D. Radanović, M.R. Milenković. Polyhedron, 128, 30 (2017).

[18] M.Č. Romanović, B. Čobeljić, A. Pevec, I. Turel, K. Anđelković, M. Milenković, D. Radanović, S. Belošević, M.R. Milenković. J. Coord. Chem., 70, 2425 (2017).

[19] Z. Otwinowski, W. Minor. Methods Enzymol., 276, 307 (1970).

[20] G.M. Scheldrick. Acta Crystallogr., Sect. A, 64, 112 (2008). 
[21] L.J. Farrugia. J. Appl. Crystallogr., 45, 849 (2012).

[22] Clinical and Laboratory Standards Institute (CLSI) 2016. Performance standards for antimicrobial susceptibility testing, 26th Informational Supplement. Approved Standard. CLSI document M100S. Wayne, PA, USA.

[23] W.J. Geary. Coord. Chem. Rev., 7, 81 (1971).

[24] K. Nakamoto, Infrared and Raman Spectra of Inorganic and Coordination Compounds, 4th Edn., Wiley-Interscience, New York, p. 283 (1986).

[25] A.W. Addison, T.N. Rao, J. Reedijk, J. Van Rijn, G.C. Verschoor. J. Chem. Soc., Dalton Trans., 1349 (1984).

[26] K. Das, T.N. Mandal, S. Roy, S. Gupta, A.K. Barik, P. Mitra, A.L. Rheingold, S.K. Kar, Polyhedron, 29, 2892 (2010).

[27] M. Bakir, M.A.W. Lawrence, M. Singh-Wilmot. J. Coord. Chem., 60, 2385 (2007).

[28] D. Kuriakose, A.A. Aravindakshan, M.R.P. Kurup. Polyhedron, 127, 84 (2017).

[29] D.J.R. Brook, S. Fornell, J.E. Stevens, B. Noll, T.H. Koch, W. Eisfeld. Inorg. Chem., 39, $562(2000)$.

[30] M. Akkurt, A.A. Khandar, M.N. Tahir, S.A.H. Yazdi, F.A. Afkhami. Acta Crystallogr., Sect. E, 68, m842 (2012).

[31] F.H. Allen. Acta Crystallogr., Sect. B, 58, 380 (2002). 
Table 1. Crystal data and structure refinement details for $\mathbf{1}$.

\begin{tabular}{|c|c|}
\hline Formula & $\mathrm{C}_{16} \mathrm{H}_{22} \mathrm{CdCl}_{2} \mathrm{~N}_{4} \mathrm{O}_{2}$ \\
\hline $\mathrm{Fw}\left(\mathrm{g} \mathrm{mol}^{-1}\right)$ & 485.67 \\
\hline Crystal size (mm) & $0.15 \times 0.13 \times 0.10$ \\
\hline Crystal color & Yellow \\
\hline Crystal system & Triclinic \\
\hline Space group & $P-1$ \\
\hline$a(\AA)$ & $8.348(5)$ \\
\hline$b(\AA)$ & $8.698(5)$ \\
\hline$c(\AA)$ & $13.748(5)$ \\
\hline$\alpha\left(^{\circ}\right)$ & $90.069(5)$ \\
\hline$\beta\left(^{\circ}\right)$ & $98.922(5)$ \\
\hline$\gamma\left({ }^{\circ}\right)$ & $98.376(5)$ \\
\hline$V\left(\AA^{3}\right)$ & $975.4(9)$ \\
\hline$Z$ & 2 \\
\hline Calcd density $\left(\mathrm{g} \mathrm{cm}^{-3}\right)$ & 1.654 \\
\hline$F(000)$ & 488 \\
\hline No. of collected reflns. & 5896 \\
\hline No. of independent reflns. & 4403 \\
\hline$R_{\text {int }}$ & 0.0163 \\
\hline No. of reflns. observed & 3769 \\
\hline No. parameters & 236 \\
\hline$R[I>2 \sigma(I)]^{a}$ & 0.0311 \\
\hline$w R_{2}(\text { all data })^{b}$ & 0.0689 \\
\hline Goof, $S^{c}$ & 1.063 \\
\hline $\begin{array}{l}\text { Maximum / minimum residual } \\
\text { electron density }\left(\mathrm{e} \AA^{-3}\right)\end{array}$ & $+0.56 /-0.61$ \\
\hline $\begin{array}{l}{ }^{a} R=\sum|| F_{\mathrm{o}}|-| l \\
{ }^{c} S=\left\{\sum\left[\left(F_{\mathrm{o}}{ }^{2}\right.\right.\right. \\
\text { reflections }\end{array}$ & $\begin{array}{l}\left.\left[w\left(F_{\mathrm{o}}^{2}\right)^{2}\right]\right\}^{1 / 2} . \\
\text { ber of } \\
\text { ers refined. }\end{array}$ \\
\hline
\end{tabular}


Table 2. Selected bond lengths $(\AA)$ and angles $\left(^{\circ}\right)$ for $\mathbf{1}$.

\begin{tabular}{llll}
\hline Bond & Distance $(\AA)$ & Angle & N1-Cd1-N2 \\
Cd1-N1 & $2.408(2)$ & N1-Cd1-O1 & $135.68(7)$ \\
Cd1-N2 & $2.278(2)$ & N1-Cd1-Cl1 & $106.32(6)$ \\
Cd1-O1 & $2.375(2)$ & N1-Cd1-C12 & $105.13(6)$ \\
Cd1-Cl1 & $2.4238(15)$ & N2-Cd1-Cl1 & $138.03(7)$ \\
Cd1-Cl2 & $2.4662(12)$ & N2-Cd1-Cl2 & $103.85(7)$ \\
N2-N3 & $1.375(3)$ & $\mathrm{Cl1-Cd1-Cl2}$ & $116.85(3)$ \\
N2-C10 & $1.275(3)$ & & \\
\hline
\end{tabular}


Table 3. Structural parameters correlating coordination geometry of structurally related fivecoordinated $\mathrm{Cd}(\mathrm{II})$ complexes.

\begin{tabular}{llllll}
\hline Complex & $\beta\left(^{\circ}\right)$ & $\alpha\left(^{\circ}\right)$ & $\tau$ & $\rho(\AA)$ & References \\
\hline$\left[\mathrm{CdLCl}{ }_{2}\right] \cdot \mathrm{CH}_{3} \mathrm{OH}(\mathbf{1})$ & $138.03(7)$ & $135.68(7)$ & 0.04 & $0.7024(2)$ & This work \\
{$\left[\mathrm{Cd}\left(\mathrm{L}^{2}\right) \mathrm{I}_{2}\right]^{\mathrm{a}}(\mathbf{2})$} & $134.17(11)$ & $132.24(8)$ & 0.03 & $0.7701(3)$ & {$[26]$} \\
{$\left[\mathrm{Cd}\left(\mathrm{L}^{3}\right) \mathrm{Cl}_{2}\right]^{\mathrm{b}}(\mathbf{3})$} & $133.61(10)$ & $130.69(9)$ & 0.05 & $0.7684(3)$ & {$[27]$} \\
{$\left[\mathrm{Cd}\left(\mathrm{L}^{4}\right) \mathrm{Br}_{2}\right]^{\mathrm{c}}(\mathbf{4})$} & $135.1(2)$ & $132.04(10)$ & 0.05 & $0.0359(4)$ & {$[28]$} \\
{$\left[\mathrm{Cd}\left(\mathrm{L}^{4}\right) \mathrm{Cl}_{2}\right]^{\mathrm{c}}(\mathbf{5})$} & $133.90(6)$ & $129.49(6)$ & 0.07 & $0.7691(2)$ & {$[28]$} \\
{$\left[\mathrm{Cd}\left(\mathrm{L}^{5}\right) \mathrm{I}_{2}\right]^{\mathrm{d}}(\mathbf{6})$} & $138.93(7)$ & $132.20(10)$ & 0.11 & $0.7638(3)$ & {$[29]$} \\
{$\left[\mathrm{Cd}\left(\mathrm{L}^{6}\right) \mathrm{Br}_{2}\right]^{\mathrm{e}}(\mathbf{7})$} & $134.55(8)$ & $127.09(6)$ & 0.12 & $0.8459(3)$ & {$[30]$} \\
\hline
\end{tabular}

${ }^{\mathrm{a}} \mathrm{L}^{2}=$ 5-methyl-1-(pyridin-2-yl)- $N^{\prime}$-[pyridine-2-ylmethylidene]pyrazole-3-carbohydrazide

${ }^{\mathrm{b}} \mathrm{L}^{3}=N, N, O$-di-2-pyridyl ketone thiophene-2-carboxylic acid hydrazone

${ }^{\mathrm{c}} \mathrm{L}^{4}=$ di-2-pyridyl ketone benzoylhydrazone

${ }^{\mathrm{d}} \mathrm{L}^{5}=1^{\prime}$-methyl-2'-(2"-pyridylmethylene)-hydrazino-1-methyl carbonic hydrazide

${ }^{\mathrm{e}} \mathrm{L}^{6}=$ methyl-2-pyridyl ketone picolinoyl hydrazone 
Table 4. Intermolecular $\pi \cdots \pi$ interaction parameters for $\mathbf{1}$.

\begin{tabular}{llllllll}
\hline $\operatorname{Cg}(\mathrm{I})^{\mathrm{a}}$ & $\operatorname{Cg}(\mathrm{J})^{\mathrm{a}}$ & $\begin{array}{l}\operatorname{Cg}(\mathrm{I})-\operatorname{Cg}(\mathrm{J})^{\mathrm{b}} \\
(\AA)\end{array}$ & $\alpha^{\mathrm{c}}\left({ }^{\circ}\right)$ & $\beta^{\mathrm{d}}\left(^{\circ}\right)$ & $\begin{array}{l}\gamma^{\mathrm{e}} \\
\left.{ }^{\circ}\right)\end{array}$ & $\begin{array}{l}\text { Slippage } \\
(\AA)\end{array}$ & $\begin{array}{l}\text { Sym. code on } \\
(\mathrm{J})\end{array}$ \\
\hline $\operatorname{Cg}(1)$ & $\operatorname{Cg}(1)$ & $3.870(3)$ & 0 & 28.3 & 28.3 & 1.833 \\
$\operatorname{Cg}(1)$ & $\operatorname{Cg}(2)$ & $5.239(4)$ & $0.99(14)$ & 49.2 & 50.0 & $2-\mathrm{x}, 1-\mathrm{y}, 2-\mathrm{z}$ \\
$\operatorname{Cg}(2)$ & $\operatorname{Cg}(2)$ & $3.508(3)$ & 0 & 17.1 & 17.1 & 1.029 & $2-\mathrm{x}, 1-\mathrm{y}, 2-\mathrm{z}$ \\
$2-\mathrm{x},-\mathrm{y}, 2-\mathrm{z}$ \\
$\mathrm{Cg}(1)$ & $\operatorname{Cg}(2)$ & $3.674(3)$ & $0.99(14)$ & 23.7 & 24.4 & & $2-\mathrm{x},-\mathrm{y}, 2-\mathrm{z}$ \\
\hline
\end{tabular}

${ }^{a}$ Labels of aromatic rings: $(1)=\mathrm{N}(1), \mathrm{C}(1)-\mathrm{C}(4), \mathrm{C}(9) ;(2)=\mathrm{C}(4)-\mathrm{C}(9)$.

${ }^{\mathrm{b}} \mathrm{Cg}(\mathrm{I})-\mathrm{Cg}(\mathrm{J})=$ Distance between ring centroids (Ang.).

${ }^{\mathrm{c}} \alpha=$ Dihedral angle between planes (I) and (J) (Deg).

${ }^{\mathrm{d}} \beta=$ Angle between $\mathrm{Cg}(\mathrm{I})-\mathrm{Cg}(\mathrm{J})$ vector and normal to plane (I) $(\mathrm{Deg})$.

${ }^{\mathrm{e}} \gamma=$ Angle between $\mathrm{Cg}(\mathrm{I})-\mathrm{Cg}(\mathrm{J})$ vector and normal to plane (J) (Deg).

${ }^{\mathrm{f}}$ Slippage $=$ Distance between $\mathrm{Cg}(\mathrm{I})$ and perpendicular projection of $\mathrm{Cg}(\mathrm{J})$ on ring $\mathrm{I}(\mathrm{Ang})$. 
Table 5. Selected average bond lengths and angles obtained by DFT for Cd-1, Cd-2 and Cd-3.

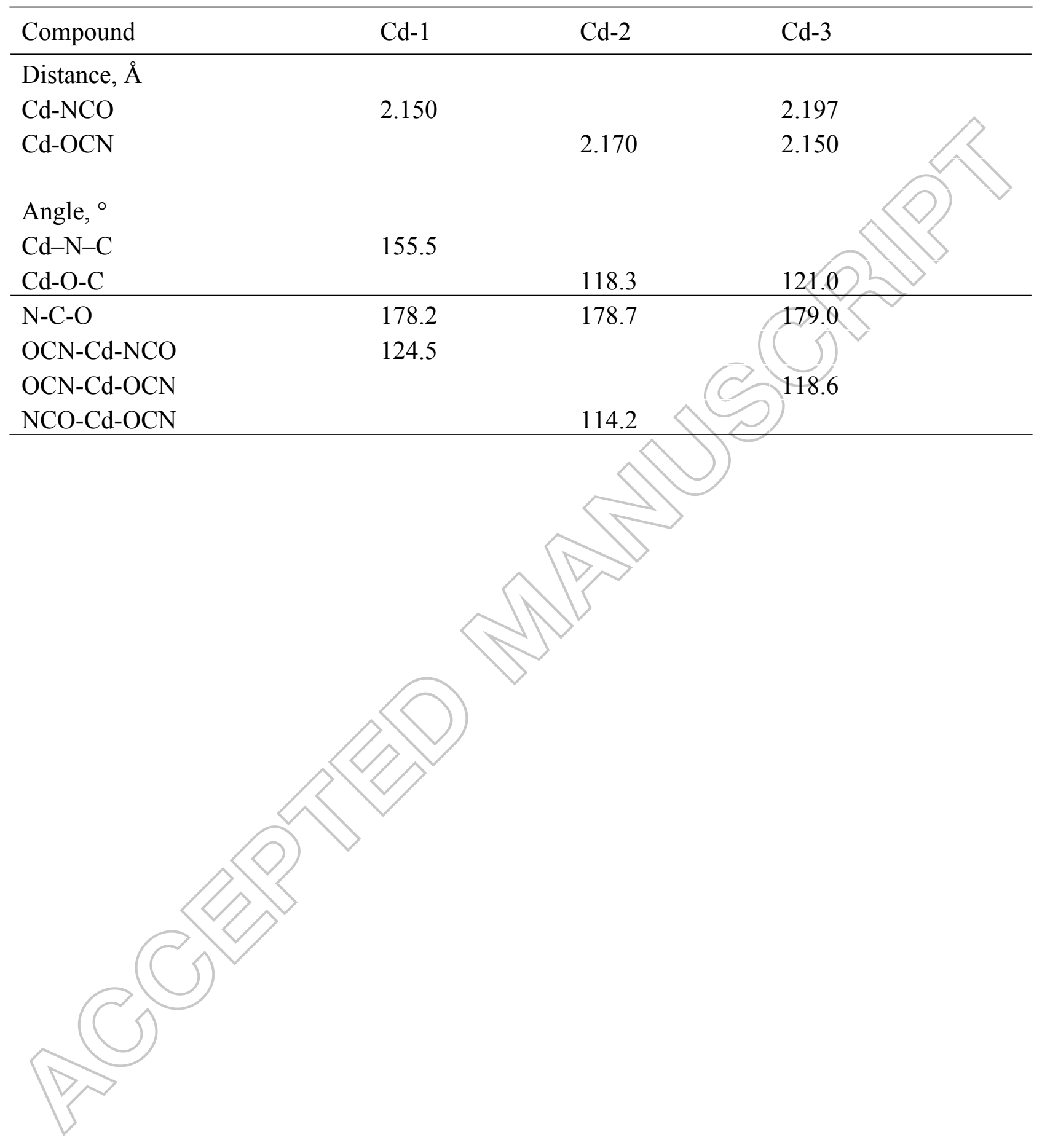


Table 6. Antimicrobial activity of $\mathrm{HLCl}, \mathbf{1}, \mathbf{2}, \mathrm{NaOCN}$ and $\mathrm{Cd}\left(\mathrm{NO}_{3}\right)_{2} \cdot 4 \mathrm{H}_{2} \mathrm{O}(\mathrm{MIC}$ values are given in $\mathrm{mM}$ ).

\begin{tabular}{|c|c|c|c|c|c|c|c|}
\hline $\begin{array}{l}\text { Microorganism } \\
\mathrm{s}\end{array}$ & $\begin{array}{l}\text { HLC } \\
1\end{array}$ & 1 & 2 & $\begin{array}{l}\mathrm{NaOC} \\
\mathrm{N}\end{array}$ & $\begin{array}{l}\mathrm{Cd}\left(\mathrm{NO}_{3}\right)_{2} \cdot 4 \mathrm{H}_{2} \\
\mathrm{O}\end{array}$ & $\begin{array}{l}\text { Meropenem } \\
*\end{array}$ & $\begin{array}{l}\text { Amphotericin } \\
*\end{array}$ \\
\hline S. aureus & 1.63 & 2.20 & 0.53 & $>$ & \multirow[t]{2}{*}{3.241} & \multirow[t]{2}{*}{0.004} & \multirow[t]{2}{*}{ n.t. } \\
\hline ATCC 6538 & 0 & 4 & 5 & 15.385 & & & \\
\hline S. epidermidis & 1.63 & 0.55 & 0.53 & $>$ & \multirow[t]{2}{*}{3.241} & \multirow[t]{2}{*}{0.003} & \\
\hline ATCC 12228 & 0 & 1 & 5 & 15.385 & & & \\
\hline B. subtilis & 3.26 & 1.10 & 0.53 & $>$ & \multirow[t]{2}{*}{0.202} & \multirow[t]{2}{*}{0.005} & \\
\hline ATCC 6633 & 0 & 2 & 5 & 15.385 & & & \\
\hline E. coli & $>$ & 1.10 & 0.26 & $>$ & \multirow[t]{2}{*}{0.404} & \multirow{2}{*}{0.006} & n.t. \\
\hline ATCC 10536 & $\begin{array}{l}3.26 \\
0\end{array}$ & 2 & 8 & 15.385 & & & \\
\hline K. pneumoniae & 1.63 & 2.20 & 0.53 & $>$ & \multirow[t]{4}{*}{0.808} & \multirow{4}{*}{$\begin{array}{l}0.008 \\
0.010\end{array}$} & \multirow[t]{2}{*}{ n.t. } \\
\hline ATCC13883 & 0 & 4 & 5 & 15.385 & & & \\
\hline \multirow{2}{*}{$\begin{array}{l}\text { P.aeruginosa } \\
\text { ATCC } 9027\end{array}$} & $>$ & $>$ & 1.07 & $>$ & & & \multirow[t]{2}{*}{ n.t. } \\
\hline & $\begin{array}{l}3.26 \\
0\end{array}$ & $\begin{array}{l}2.20 \\
4\end{array}$ & 1 & 15.385 & & & \\
\hline S.enterica & $>$ & 2.20 & 0.53 & $>$ & & \multirow[t]{2}{*}{0.006} & \multirow[t]{2}{*}{ n.t. } \\
\hline ATCC 6017 & $\begin{array}{l}3.26 \\
0\end{array}$ & 4 & 5 & & & & \\
\hline C. albicans & $>$ & 0.55 & 0.53 & & \multirow[t]{2}{*}{0.202} & \multirow[t]{2}{*}{ n.t. } & \multirow[t]{2}{*}{0.0005} \\
\hline ATCC 10231 & $\begin{array}{l}3.26 \\
0\end{array}$ & 1 & & 15.385 & & & \\
\hline
\end{tabular}

n.t. not tested

* reference antimicrobial drugs 


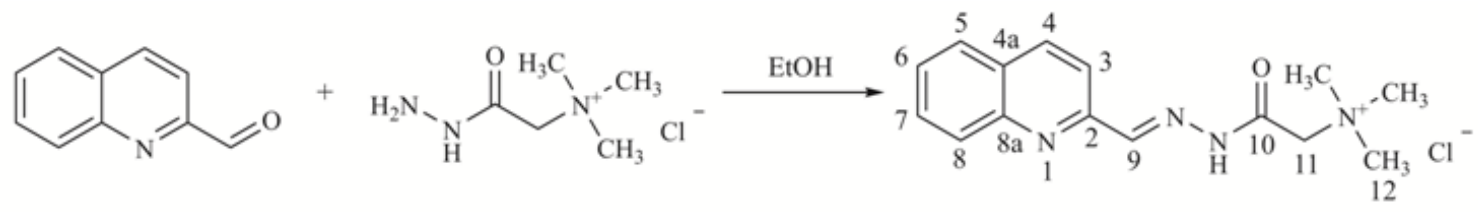

HLCl
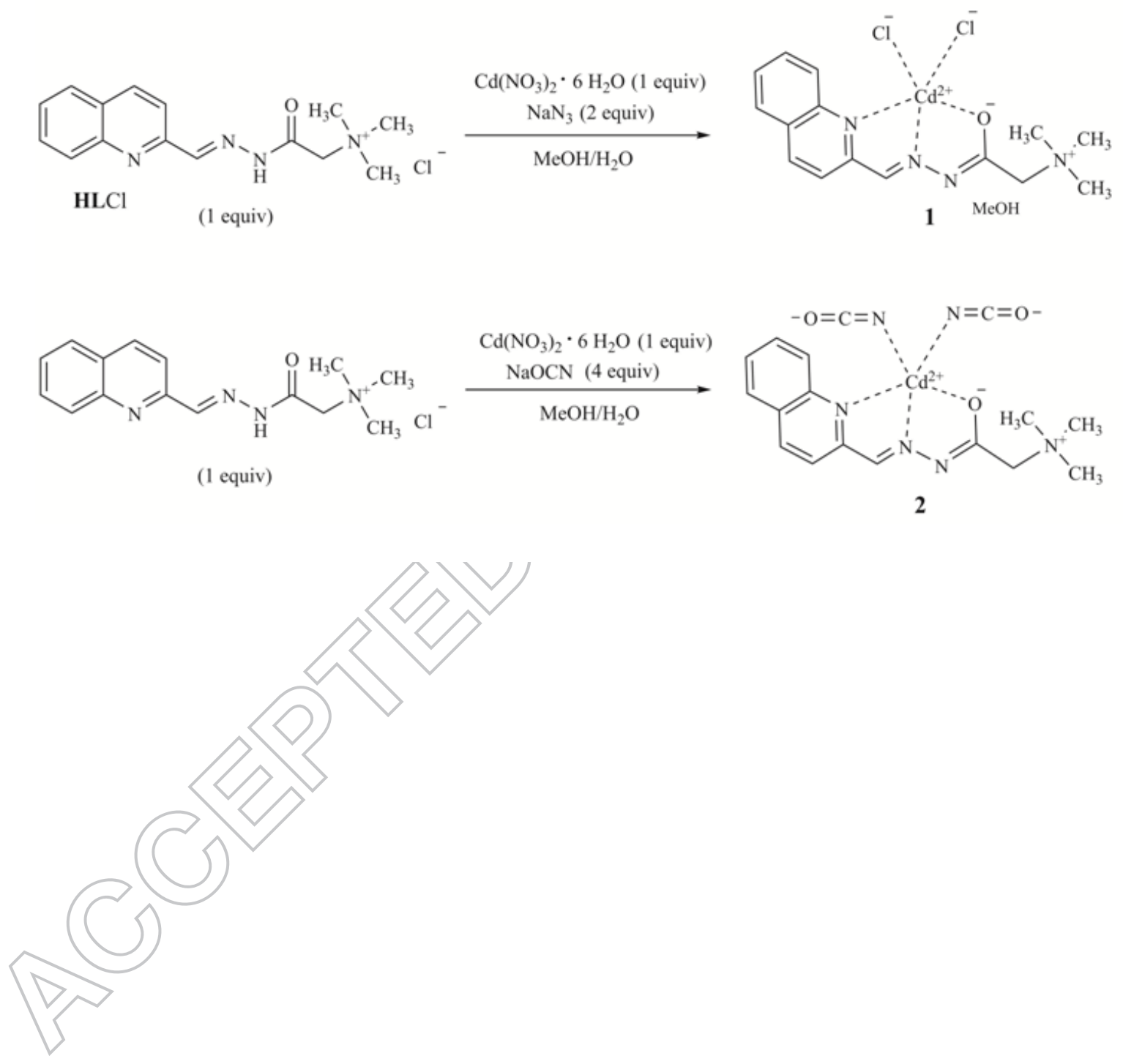

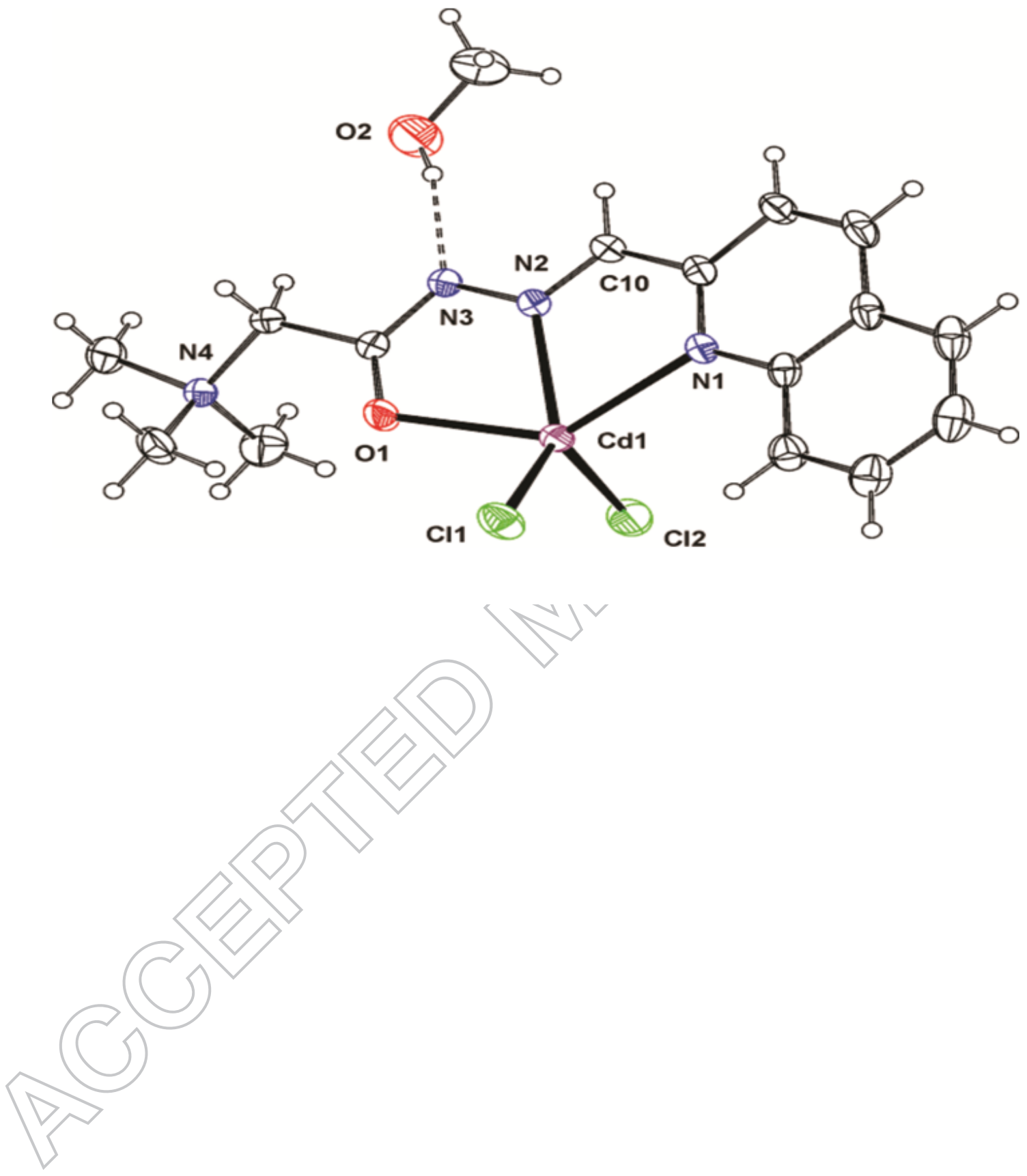


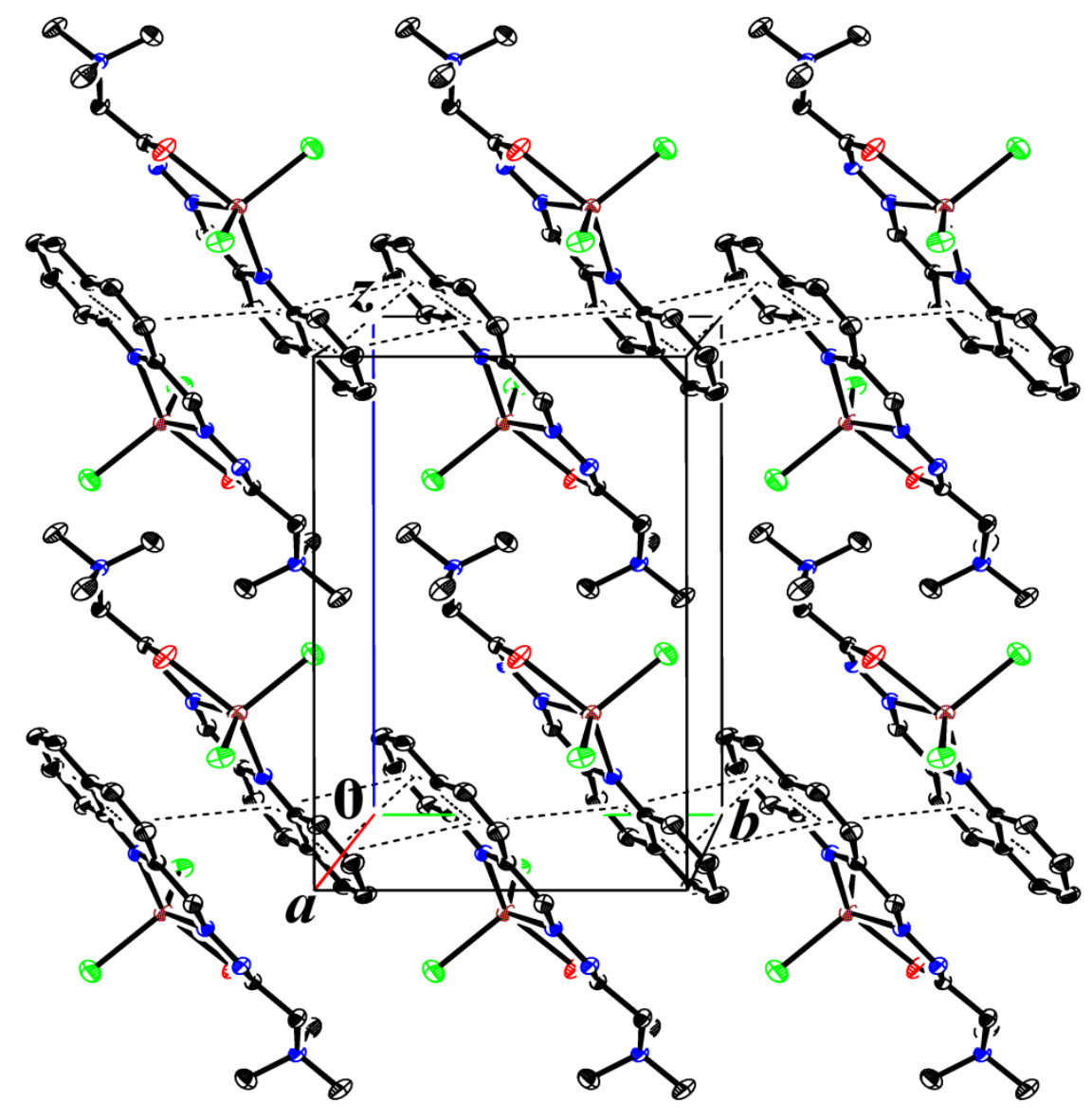




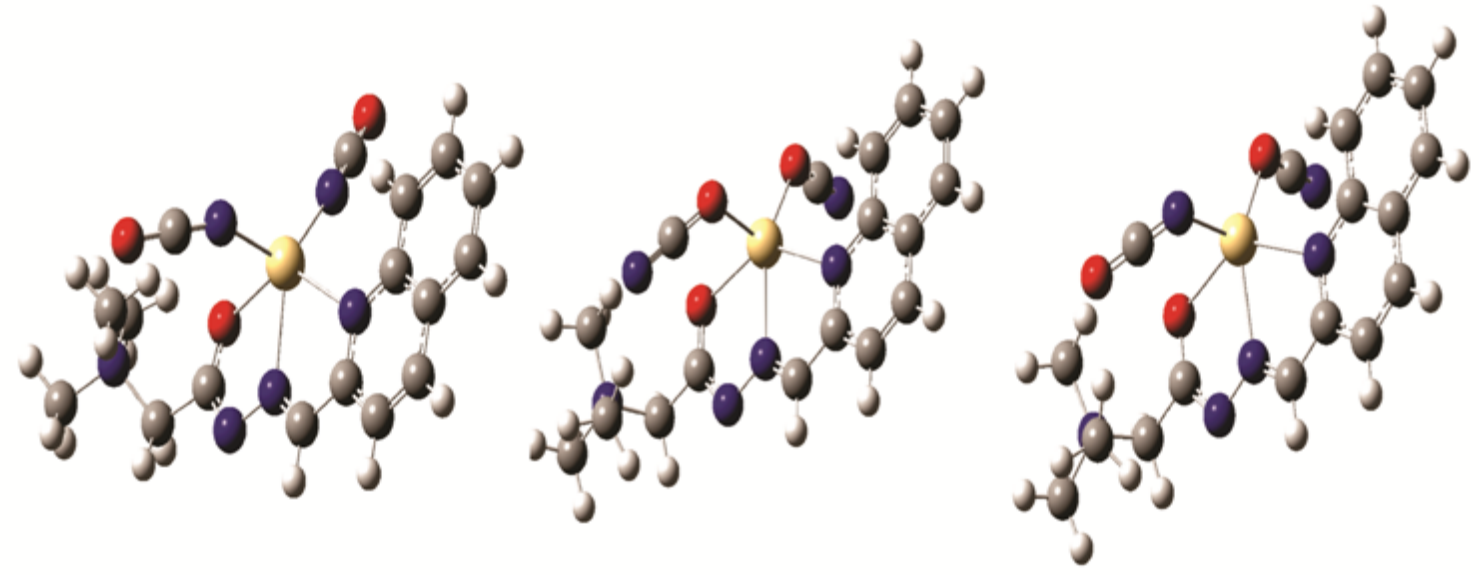

a)

b)

c) 


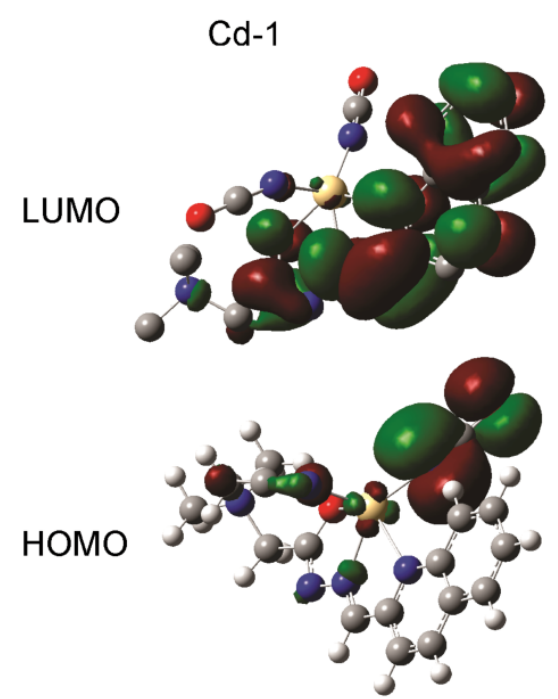

a)
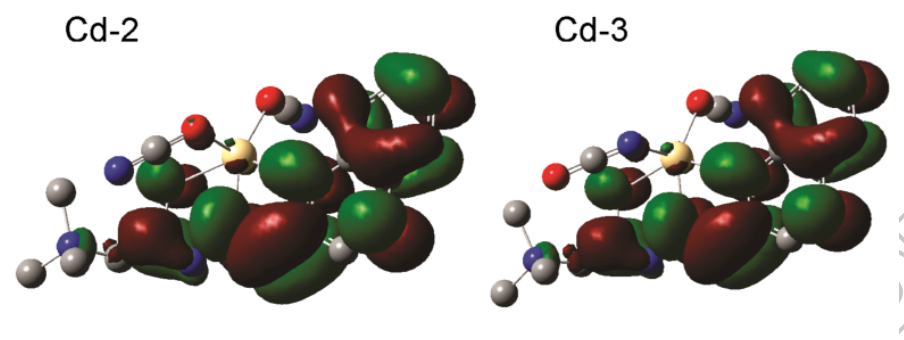

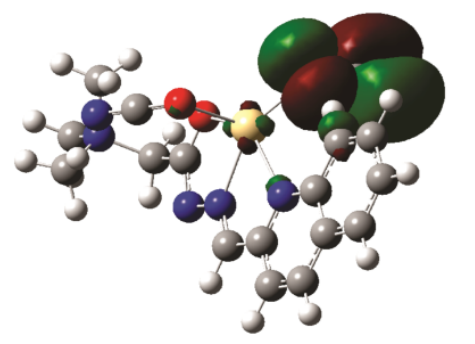

b)

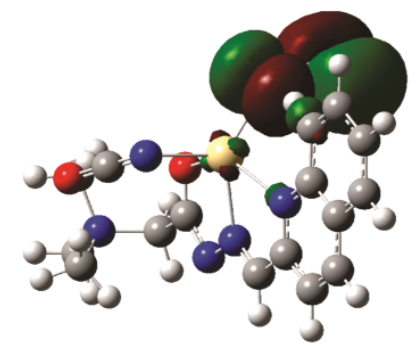

c)

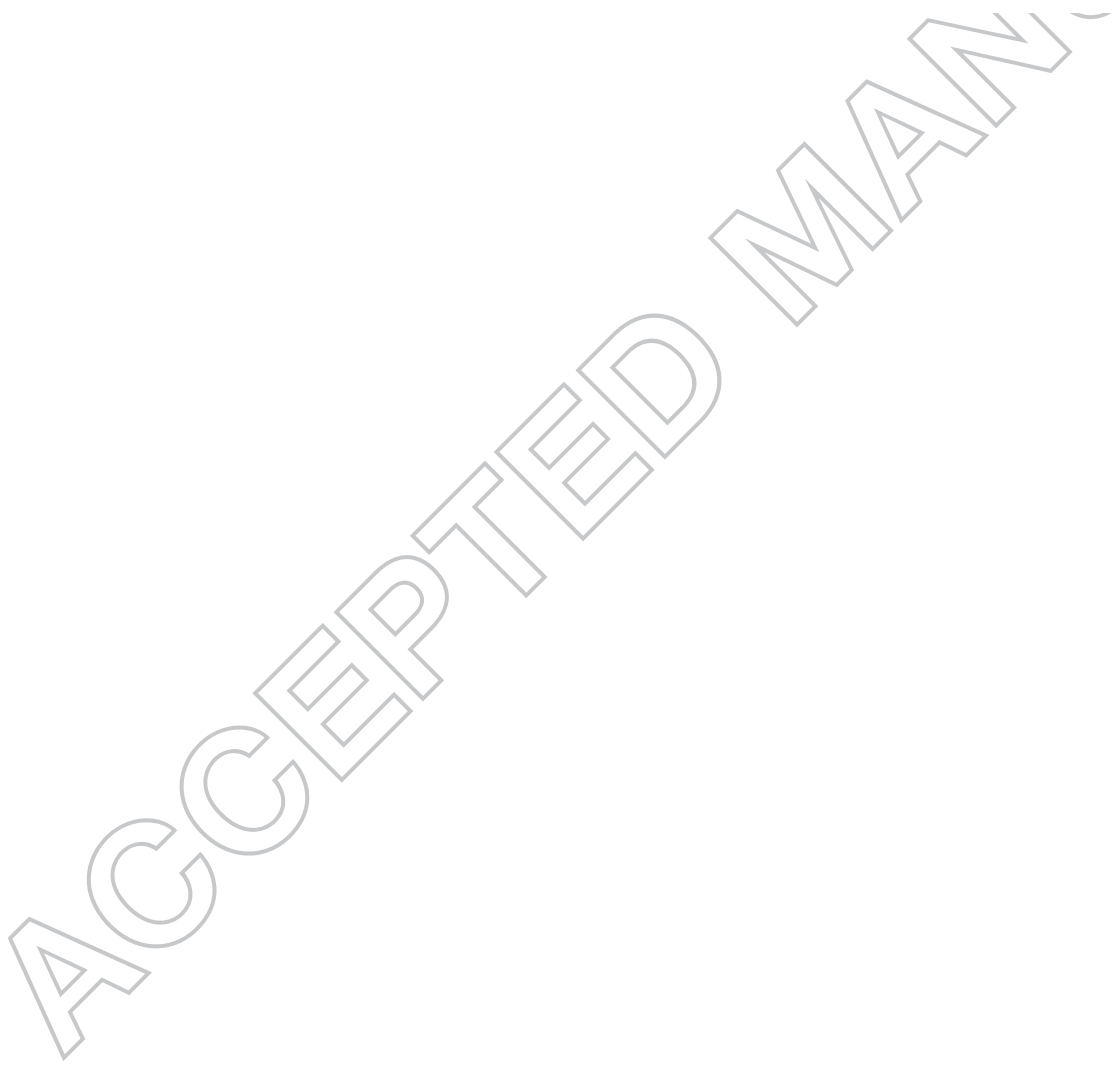



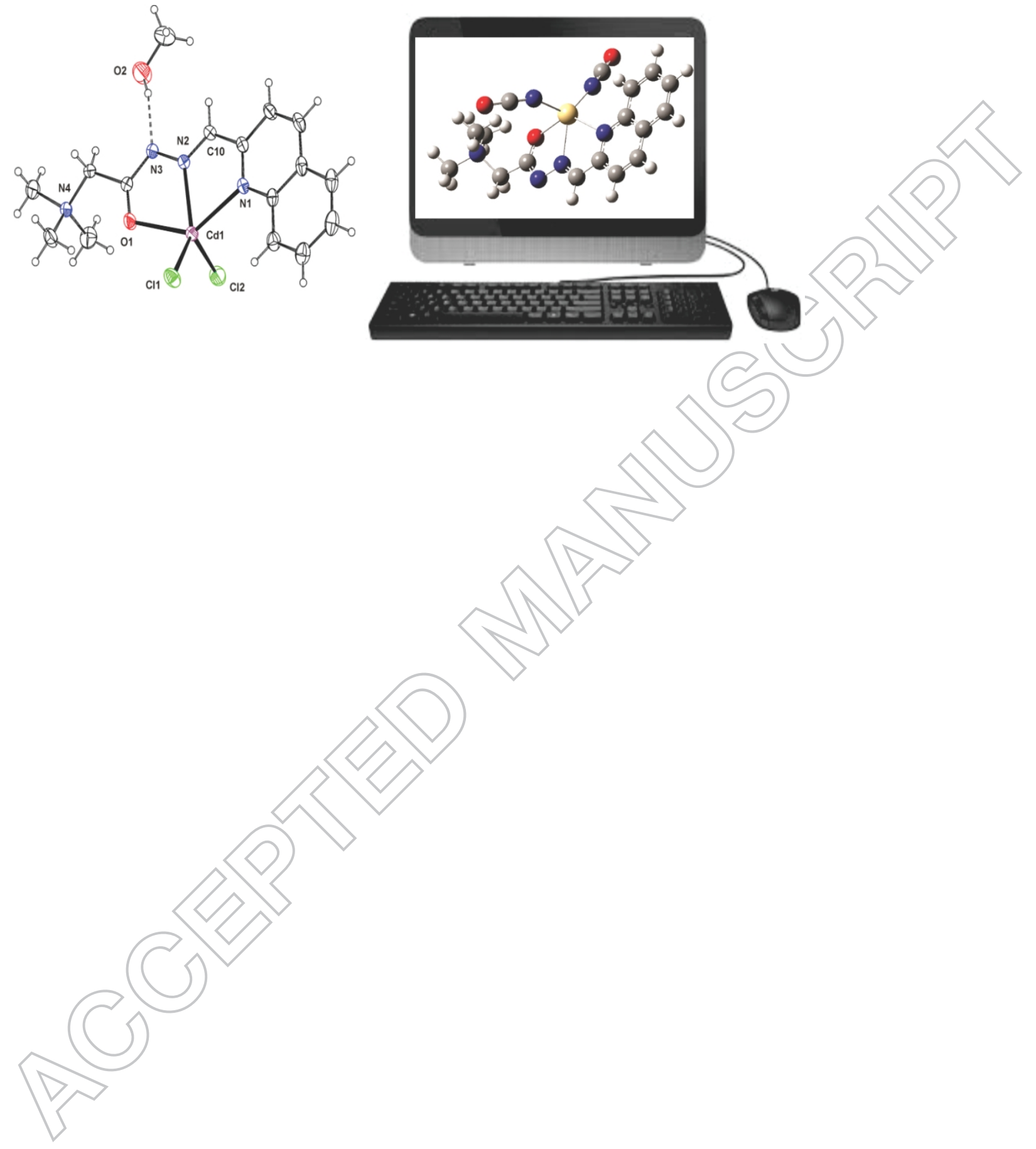